\title{
THE INFLUENCE OF CLIMATE CHANGE ON THE ESCALATING COMMUNAL CONFLICT BETWEEN HERDSMEN AND FARMERS: THE CASE OF THE FULANI ETHNIC GROUP IN NIGERIA
}

\begin{abstract}
Gustavo Furini
gustavofurini@gmail.com

Ph.D. student in International Relations: Geopolitics and Geoeconomics at Universidade Autónoma de Lisboa - UAL (Portugal). Holder of a master degree in Natural Resource Management and Local Development in the Amazon from UFPA (Brazil) and of a bachelor degree in Geography from UFRGS (Brazil). Has been working in the area of climate change since 2005, with experience in the public and private sectors.
\end{abstract}

\section{Abstract}

Current scientific evidence shows that human activities are causing interference at different levels in the global climate and availability of natural resources, and many authors already relate water scarcity to the increased risk of violent conflict, particularly in rural societies on the African continent. Climate disruptions caused by climate change are reflected on a regional and local scale, and the greatest impacts are already being felt in the poorest areas of the planet. Nigeria, Africa's most populous country, has been facing environmental problems in its territory that can be associated with climate change, such as rising temperatures, reduced rainfall and advancing desertification. Considering that all these phenomena have been worsening since the early twentieth century in Nigeria and, due to the escalating of violent conflicts since the beginning of the current century, the objective of this paper is to analyse how climate change can interfere in the conflict between herdsmen and farmers, as well as the possible impact of seasonal variation in rainfall on the dynamics of these communal conflicts. The study focused on literature review and the case study took place in four Nigerian states (Plateau, Benue, Taraba and Nasarawa) for the period 2010-2017, focusing on the communal conflict involving the Fulani ethnic group. The approach adopted was the inductive method in which the behaviour of rainfall in the study area was compared with the number of deaths resulting from the conflict, in addition to using geo-processing software to understand the spatial and temporal distribution of casualties. The theoretical framework used was that proposed by Thomas Homer-Dixon (1994) and the information was collected from primary sources, with consultation of qualitative and quantitative data, and from secondary sources through book reviews, publications and papers in scientific journals. While it is not yet possible to establish a direct and linear relationship between climate change and violent conflict, the revised literature indicates that competition for water and other natural resources in certain parts of Nigeria is increasing, and that the violent conflicts between Fulani herdsmen and farmers are increasing due to the dispute over access to water sources and grazing lands. Data analysis shows that in the study area there are $46.4 \%$ more deaths in the dry season (November to April) than in the rainy season (May to October). While there are still not enough elements to conclude that climate change is the primary cause of the conflict, the analysis reinforces the need, in certain contexts, particularly in developing countries with populations highly dependent on the primary sector of the economy, for the impacts of climate change to be seriously considered as a risk to human security.

\section{Keywords}

Climate change; Communal conflict; Nigeria; Fulani; Water.

\section{How to cite this article}

Furini, Gustavo (2019). "The influence of climate change on the escalating communal conflict between herdsmen and farmers: the case of the Fulani ethnic group in Nigeria". JANUS.NET e-journal of International Relations, Vol. 10, N.0 2, November 2019-April 2020. Consulted [online] on the date of the last visit, https://doi.org/10.26619/1647-7251.10.2.3 


\title{
THE INFLUENCE OF CLIMATE CHANGE ON THE ESCALATING COMMUNAL CONFLICT BETWEEN HERDSMEN AND FARMERS: THE CASE OF THE FULANI ETHNIC GROUP IN NIGERIA ${ }^{12}$
}

\author{
Gustavo Furini
}

\section{Introduction}

With the end of the Cold War, the definition of the concept of security came to have a broader understanding, incorporating new dimensions that surpassed the exclusively state bias (Tomé, 2012). In addition to military issues, social, economic, and environmental factors have incorporated the list of elements necessary to ensure world peace and security since the 1990s (Dannreuther, 2013; Sheehan, 2005; UNSC, 1992). In this context of broadening the understanding of security, the challenges posed by the scarcity of natural resources ${ }^{3}$ have also been considered (Homer-Dixon, 1994), in view of the recognition that the tensions generated around access and use of natural resources have the ability to unleash violent conflicts ${ }^{4}$ between different actors and groups, especially on an intrastate scale (Conca \& Wallace, 2012).

The challenges posed by environmental risks $^{5}$ stem mainly from society's misuse of natural resources, which has led to problems such as depletion of arable land, irreversible loss of biodiversity, pollution of soil, water and air (Dannreuther, 2013; Sheehan, 2005). Among the various negative impacts caused to the environment, we highlight climate change, which according to scientific evidence, results from the constant and growing emission of greenhouse gases into the atmosphere, especially due to the burning of fossil fuels (IPCC, 2013). Climate change has the capacity to widen social disparities through

1 The translation of this article was co-funded by Instituto Camões in the framework of the 1st International Conference on Conflict Resolution and Peace Studies. Text translated by Carolina Peralta.

2 Special issue of articles presented at the 1st International Conference on Conflict Resolution and Peace Studies that took place at UAL on the $29^{\text {th }}$ and $30^{\text {th }}$ of November 2018.

3 Natural or environmental resources are stocks of materials that exist in the natural environment, renewable and non-renewable, which, depending on their use, can be considered common goods or have economic value (WTO, 2010).

4 The understanding of violent conflict provided by The African Centre for the Constructive Resolution of Disputes (ACCORD, 2012) is used here, where lethal violence is used by the parties in the conflict to obtain the disputed resource, such as land or power.

5 The negative effects of climate change are normally taken as security "threats", however, it was decided to use the understanding given by SIPRI (2016) which considers that climatic changes are associated to "risks", since the climate crisis is a direct consequence of anthropogenic action. In addition, the challenges posed to mankind due to man-made actions on the environment over the last couple of centuries, as the case of climate change, fit the understanding of "Risk Society" proposed by Ulrich Beck (2016). According to the author, the processes of industrialization and modernization of the society have promoted environment imbalances, and the responses created by the environment seeking for a new momentum of balance have brought risks for social dynamics in general, including those related to security issues (Beck, 2017). 
worsening poverty, hunger, forced human mobility and greater difficulty in accessing natural resources, especially in developing countries, historically responsible for the lowest greenhouse gas contributions, but in contrast, those that are most vulnerable to climate change (IPPC, 2014).

Analyses of data collected from the atmosphere, land and ocean confirm that phenomena arising from climate change are already occurring, to a greater or lesser extent, throughout the planet, and such changes are associated with a major threat to social and economic stability of societies (IPCC, 2013). Observations and studies indicate that the western Sahel band, a region that includes the northern part of Nigeria, has been experiencing declining rainfall levels with longer drought periods and rising temperatures over the last decades (Assibong et al., 2017). This water variability has a negative impact on the availability of resources for people using the land as their livelihood, a scenario aggravated by the increasing pressure exerted by population growth in Nigeria ${ }^{6}$ (Eze, 2018).

The number of researchers examining the possible relationships between climate factors and non-state conflicts is growing (FOI, 2010), so there is a convergence that, in certain situations, the variation in water availability in primary sector dependent economies may influence violent conflicts, particularly in rural and pastoral societies in the African continent (IPCC, 2013; ACCORD, 2012). Given this, climate change has the ability to interfere, even indirectly, on the dynamics of violent conflicts, especially intra-state conflicts, since they can intensify poverty and aggravate economic crises, events that are already well documented as factors that directly influence the conflicts (IPCC, 2014).

And this is precisely what is happening in the central-eastern and northern regions of Nigeria, where it is possible to verify a gradual reduction in the availability of certain natural resources, especially water and arable land, which has been linked to records of rising temperatures and lower rainfall (Idowu, 2017; Okoli \& Atelhe, 2014; CCASTR, 2011). Such diminished access to natural resources is seen as a major cause of the escalation of non-state conflicts between herdsmen and farmers in central-eastern and northern parts of the country (Uze, 2018; Freeman, 2017).

In this context, this paper focuses on two objectives: i) initially, we sought to analyse based on the theory on the subject how the growing scarcity of natural resources, especially the scarcity of water, which has being aggravated by climate change according to scientific observation, applies to communal conflicts involving the Fulani ethnicity, especially in rural areas in the northern and central-eastern parts of Nigeria; and secondly, ii) it was verified how the seasonal variation in water availability, analysed from the rainfall index data in the rainy season (May-Oct) and the dry season (Nov-Apr), from 2010 to 2017, relates to the dynamics of communal conflicts involving the Fulani ethnicity in four Nigerian states (Plateau, Benue, Taraba and Nasarawa) located in the centraleastern zone of the country.

After revision of the theory, it was decided to take the approach proposed by Thomas Homer-Dixon (1994), which connects environmental scarcity to violent conflicts, especially those of ethnic origin at intrastate level. The work was carried out based on the case study analysis and information collected from primary sources (conflict database

6 According to World Bank data, the total population of Nigeria in 2018 was estimated at about 196 million. Available at: https://data.worldbank.org/country/nigeria. Accessed on 20/06/2019. 
provided by the $\mathrm{UCDP}^{7}$ ), and from the review of secondary sources (books, publications and papers in scientific journals).

Besides this introduction, the paper has four sections. The first part addresses the inclusion of environmental factors, especially climate change, in the broader understanding of post-Cold War security. The next section discusses the nexus between climate change and violent conflict, and examines how climate change can negatively affect the availability of natural resources, which in turn generates or exacerbates conflict. The third section addresses the communal conflict in Nigeria between Fulani farmers and herdsmen, with a view to identifying the influence of climate change on this conflict by reducing the availability of natural resources, especially water. The fourth part of this paper presents the case study that the interference of rain in violent, with fatal attacks involving the Fulani ethnic group in four Nigerian states. At the end of the document, the conclusion and references used are presented.

\section{The inclusion of climate change in the understanding of security}

Environmental issues have been formally on the international agenda since the late $1960 \mathrm{~s}$ and early 1970s, culminating in the Stockholm Conference in 1972, however, at that time central security issues were determined by the Cold War (Sheehan, 2005). The notion that humanity was causing irreparable damage to the environment and the fear of nuclear catastrophe were the main concerns of the environmental agenda at the time (ibid.). During the Cold War period, security concerns were directly related to state military action and thus, there was no room for discussion of issues such as environmental security (Dannreuther, 2013). Moreover, such a classic concept of state protection security lasted for more than three centuries, from the creation of Weber's notion of the state until the early 1990s (FOI, 2010).

However, the global changes and challenges that emerged on the international scene at the end of the last century have brought with it the need to include topics such as economics, demographics and the environment in order to have a better understanding of the new directions of security (Mathews, 1989). The exclusivism of the state-centric bias that had guided security institutions so far was not adequate to cope with the new challenges ahead (ibid.). Thus, the end of the Cold War allowed the emergence of interpretations other than those that favoured only the state approach, which enabled a broader understanding of security (Tomé, 2010). Such understanding has come to depend on the interaction between various factors and, in this list of new dimensions, the environmental issue and related themes, such as climate change, are included (ibid). As evidence of the change in the international scene, in January 1992 the United Nations Security Council presidency issued a note emphasizing that the end of wars and armed conflicts between states alone were not sufficient to ensure international security, admitting that social, economic, humanitarian and ecological issues have become potential sources of instability for security and peace (UNSC, 1992).

Faced with this scenario of transformation between the late 1980s and the early 1990s, the environmental theme became part of security studies, and exposed the need to formulate and develop theories and concepts with a view to delimiting the object of study (Sheehan, 2005). From this perspective, it is possible to highlight the concept of

7 Uppsala Conflict Data Programme (UCDP). 
environmental security, which, although its definition still causes heated debate until today (Soromenho-Marques, 2015), has been used to address the environmental risks that emerge from natural systems due to human interference (Dannreuther, 2013). Examples include misuse of natural resources, deforestation, disorderly land use, contamination of water and atmosphere, and climate change (Sheehan, 2005; HomerDixon, 1994). Anthropic activities began to interfere in natural processes in such a way that the "Risk Society" began to suffer from the consequences dictated by itself (Beck, 2016), strengthening the understanding that we are living in the Anthropocene ${ }^{8}$ period. Addressing the issue of environmental security raises the concatenation of methodological precepts of the environmental sphere with disciplines that traditionally address security issues, such as strategy and international relations (SoromenhoMarques, 2015).

Moreover, the discourses that address climate change tend to adopt the concept of "human security" whose origin is attributed to the Human Development Report, published by the UNDP in 1994 (FOI, 2010). The paper proposes an integrative concept and involves seven different dimensions of security: economic, personal, community, political, food, health and environmental (UNDP, 1994). This concept embraces a wide range of factors based on the understanding that conflicts will become more intense within nations, and not between them, mainly due to the lack of access to resources and socioeconomic disparities (ibid). In addition, as the concept evolves and consolidates, the fifth report of the Intergovernmental Panel on Climate Change (IPCC) has devoted an exclusive chapter to human security, addressing the risks posed by climate change, including an increased likelihood of violent conflict in areas with high levels of economic, social and environmental vulnerability (IPCC, 2013).

Acute insecurity situations such as hunger, conflict and socio-political instability almost always emerge from the interaction of multiple factors (Burke et al., 2015). However, there is growing scientific recognition that climate change could undermine human security as it undermines people's livelihoods, especially through diminishing reserves and access to natural resources, and can trigger violent conflict both locally and regionally (Raimi \& Jack, 2017). The consequences of climate change must be treated as an additional environmental element for human security, from the point of view of the state to the scale of the individual (ibid.), although there are few cases in the literature that explicitly address the relationship between climate change and security, these studies indicate the existence of a nexus (IPCC, 2013). However, it is crucial to note that the academics point out that the relationship between climate change and human security is mostly indirect, and consider that climate change has a catalytic effect in certain contexts of violent conflict (Penny, 2018; Raimi \& Jack, 2017; Buhaug, 2016; Uexkull et al., 2016; Burke et al., 2015; Salehyan, 2014; UNGA, 2009).

\section{Climate change, scarcity of natural resources and violent conflict}

In the 1990s, Thomas Homer-Dixon was one of the pioneers to relate problems of access to natural resources to security and violent conflict (Dannreuther, 2013). The author assumed that changes in the environment caused by humans, which have the ability to

8 The Anthropocene marks a time when the magnitude of human interference in the environment is such that society can be characterized as a geophysical force of global influence, capable of having negative impacts in various areas, including in terms of security (Dalby, 2017). 
directly affect not only the quality but also the quantity of natural resources, together with population growth and the unequal geographical distribution of natural resources, constitute the tripod of environmental scarcity (Homer-Dixon, 1994). The author argues that environmental scarcity can, under certain circumstances, disrupt security due to its ability to interfere with social, political and economic processes, and in weakened states, the rise in social tension caused by the scarcity of natural resources may culminate in escalating levels of intra-state violence (ibid.).

Although case studies have been able to document and link the degradation or unavailability of natural resources to the occurrence of violent conflict, the theory has been questioned on the basis of weaknesses in establishing a causal relationship (Dannreuther, 2013). The many variables in the social context, especially in economic and political terms, make it difficult to identify a causal link between variations in environmental availability and violent conflict (SIDA, 2018; SIPRI, 2016; Conca \& Wallace, 2012). However, the lack of quantitative studies that are statistically robust to confirm the direct link between environmental causes such as climate and violent conflict alone cannot be taken as a parameter to completely rule out any kind of influence (Burke et al., 2015; UNGA, 2009).

Moreover, the scientific community has recognized that environmental factors have the ability to exacerbate conflict indirectly through multiple forms, as they aggravate existing social, political and economic tensions (Penny, 2018; Freeman, 2017; IPCC, 2013; ACCORD, 2012; FOI, 2010; UNGA, 2009). It should also be considered that the difficulty encountered in demonstrating the existence of a direct and linear relationship between environmental issues and violent conflicts reinforces the idea that responsibility rarely falls under a single factor, but rather results from a succession of interconnected events (Raimi \& Jack, 2017; FOI, 2010). In terms of climate change, the difficulty in establishing this direct relationship is mainly due to the low probability of groups deciding to conflict simply because the heat has intensified or due to the decrease in the amount of rain, however, negative impacts from climate change such as drought and desertification can lead to violent conflict (Buhaug, 2016).

Each society's social and environmental vulnerability will determine whether the negative impacts of climate change will lead to conflict (Buhaug, 2016; Scheffran et al., 2012). In this regard, communities highly dependent on agriculture and livestock, located in poor countries with low climate response capacity, may be in conflict over the use of natural resources that have become scarce due to the effects of rising temperatures or falling rain levels (Buhaug, 2016; Theisen et al., 2011). On the other hand, a society located in a rich country whose resilience is based on technological development to adapt to change, as well as on the responsiveness of its public and private institutions, would hardly have to deal with violent conflict due to the negative effects of climate change (Salehyan, 2014; Theisen et al., 2011).

The question that must to be asked is not "whether" climate change influences violent conflict, but "when" and "how" it happens (Salehyan, 2014). In order to establish any link, the analysis should take into account three dimensions, namely: i) the geographical location at which the impact of climate change occurs (spatial dimension); ii) the period in which it takes place (temporal dimension) and; iii) the responsiveness of the population and institutions to cope with the situation of environmental stress (social dimension) (ibid.). All of these dimensions are interconnected and, in order to have a concrete interpretation of a specific situation in which these dimensions are acting together, the 
analysis must be focused on an individualized scenario, avoiding generalizations and the search for standards, reinforcing, once again, the importance of context analysis (ibid.).

Changes in the environment caused by climate change can undermine human security by reducing access to certain natural resources indispensable for the livelihoods of many societies, particularly in Africa (Raimi \& Jack, 2017; FOI, 2010; UNGA, 2009). The scarcity of natural resources and the dispute over their use, such as water, could trigger violent conflicts (ACCORD, 2012), therefore variations in rainfall rates, either with increasing or decreasing rainfall, will be responsible for increasing the risk of violent conflict in highly resource-dependent economies, particularly in rural societies in Africa (IPCC, 2014). Access to water is a serious problem for many African countries, both in quantity and quality (IPCC, 2013), hence, one of the challenges in climate change studies is to predict how the behaviour of rain and temperature rise patterns will occur, since, depending on these factors, there may be additional pressure on water sources and fertile land (FOI, 2010).

It should be noted that there is debate among those who argue that there is an increasing potential risk of conflict due to water scarcity, while others use statistical data to show that tensions around the availability of this natural resource usually end with negotiation and diplomacy, especially in cross-border disputes (ibid.). However, most studies emphasize that this agreements' scenario may not be the focus in the future, particularly in intra-state terms, as climate change can aggravate water scarcity in regions with fragile governments and without the institutional capacity to manage this type of dispute between local communities (SIPRI, 2016).

Figure 1. Relationship between drought (Palmer Drought Severity Index, from 2005 to 2014) and violent conflict (UCDP, from 1995 to 2014) in part of the African continent, with focus to Nigeria inner the red circle

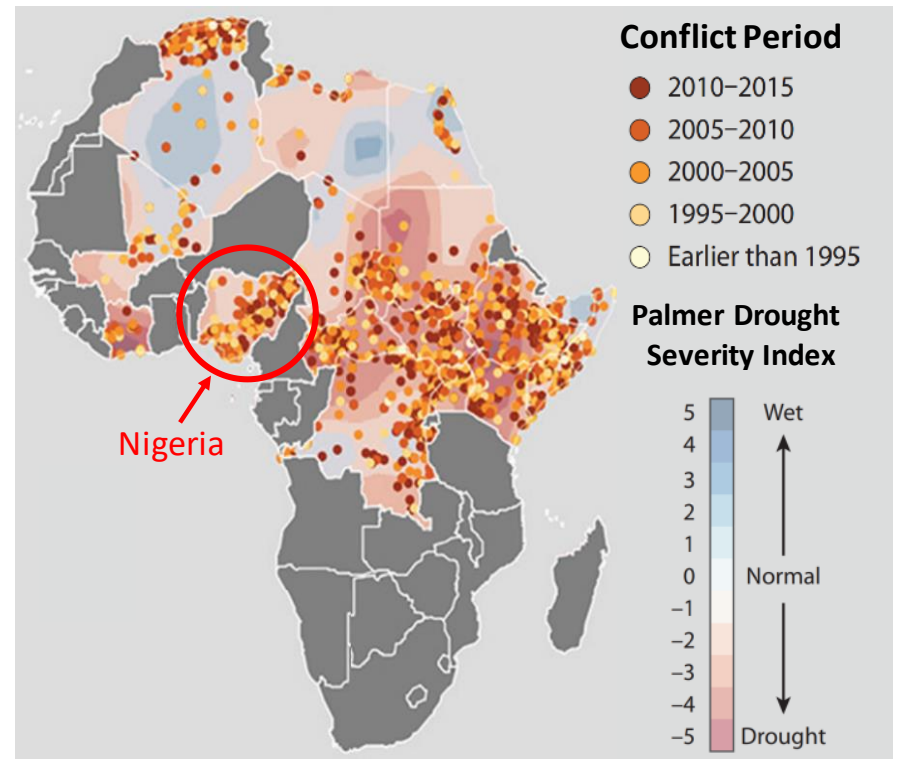

Source: Adapted from the original proposed by Koubi (2019)

Rising global temperatures are expected to induce and prolong periods of drought in many regions, particularly those already vulnerable to water scarcity, such as the African 
continent, which may influence intrastate conflicts (Koubi, 2019; Penny, 2018). Koubi's study (2019) related the drought indexes from 2005 to 2014, obtained through the Palmer Drought Severity Index (PDSI) ${ }^{9}$ method, with the data of conflicts in the African continent from 1995 to 2015 provided by the UCDP since 1995, as shown in Figure 1. Although conflict data have started a decade earlier than the drought index covers (PSDI), there is a strong concentration of violent conflict in drought-intensifying places, especially in sub-Saharan African countries, which also applies to Nigeria.

There is some consensus that climate variability on the African continent may lead to higher natural resource scarcity rates, which are the main livelihoods for a large part of the population (ACCORD, 2012). Increasing unavailability of natural resources essential for sustaining livelihoods will have a negative impact on human security, and the most devastating effects are projected for economies that are less able to adapt to such changes, which is essentially the case in developing countries (Uexkull et al., 2016). Regardless of the ongoing debate on the causal link between climate change and violent conflict, given the imminent threat to human security, it would make sense for the UN Security Council to take a more proactive stance on the matter (Scott \& Ku, 2018; Penny, 2018).

Given the Council's primary responsibility for maintaining peace and security globally, it does not seem coherent for the body to be oblivious to the discussion or to take a neutral stance in view of the extension of the phenomenon (ibid). The Security Council shows that its involvement is reactive and based on protocols on climate change issues, most likely due to resistance from some of its key members (Penny, 2018). Even in the face of this Security Council's weak participatory scenario, it is important to underline the position adopted by the Security Council with Resolution S/RES/2349/2017, in which it recognized, in a new way, climate change as a factor of instability regarding security, mainly due to interference with the availability of natural resources in Africa (UNSC, 2017). The Resolution addresses the conflicting situation that exists in the area of the Lake Chad Basin, the region in which northeast Nigeria is situated, and in its paragraph 26 recognizes that:

\begin{abstract}
"... the adverse effects of climate change and ecological changes among other factors on the stability of the Region, including through water scarcity, drought, desertification, land degradation, and food insecurity, and emphasises the need for adequate risk assessments and risk management strategies by governments and the United Nations relating to these factors... (UNSC, 2017:7)".
\end{abstract}

Thus, the absence of quantitative and statistical elements that prove the direct and linear relationship of the influence of environmental factors on violent conflicts cannot continue to serve as a pretext to play down their potential participation (Salehyan, 2014). And this appeal is even more relevant given the risks to human security caused by climate change in the least developed countries (IPCC, 2013). In light of the foregoing, the next

9 The PDSI was developed in the 1960 s and has been used to identify droughts from monthly temperature and precipitation data, as well as information on soil water retention capacity. It considers both the moisture received (precipitation) and the moisture stored in the soil, thus representing the potential moisture loss due to the influence of temperature (WMO \& GWP, 2016). 
section will address the role climate change plays in environmental scarcity in Africa, as well as its contribution to the worsening conflict between herdsmen and farmers in Nigeria who are highly dependent on the primary sector of the economy.

\section{Climate change, environmental scarcity and communal conflict in Nigeria: farmers vs. herdsmen}

Based on the concept of environmental scarcity proposed by Homer-Dixon (Figure 2), the perspective that the decrease in the quality and quantity of natural resources, aggravated by climate change, participates in the chain of events that may influence communal ${ }^{10}$ conflicts between herdsmen and farmers is used here. Such conflicts occur in several sub-Saharan African countries, presenting themselves as a challenge on a national and regional scale (Gbaka, 2014), therefore, the impact of Fulani action in Nigeria will be analysed in more detail.

Figure 2. Influence of climate change on natural resource scarcity and its relationship to communal conflicts

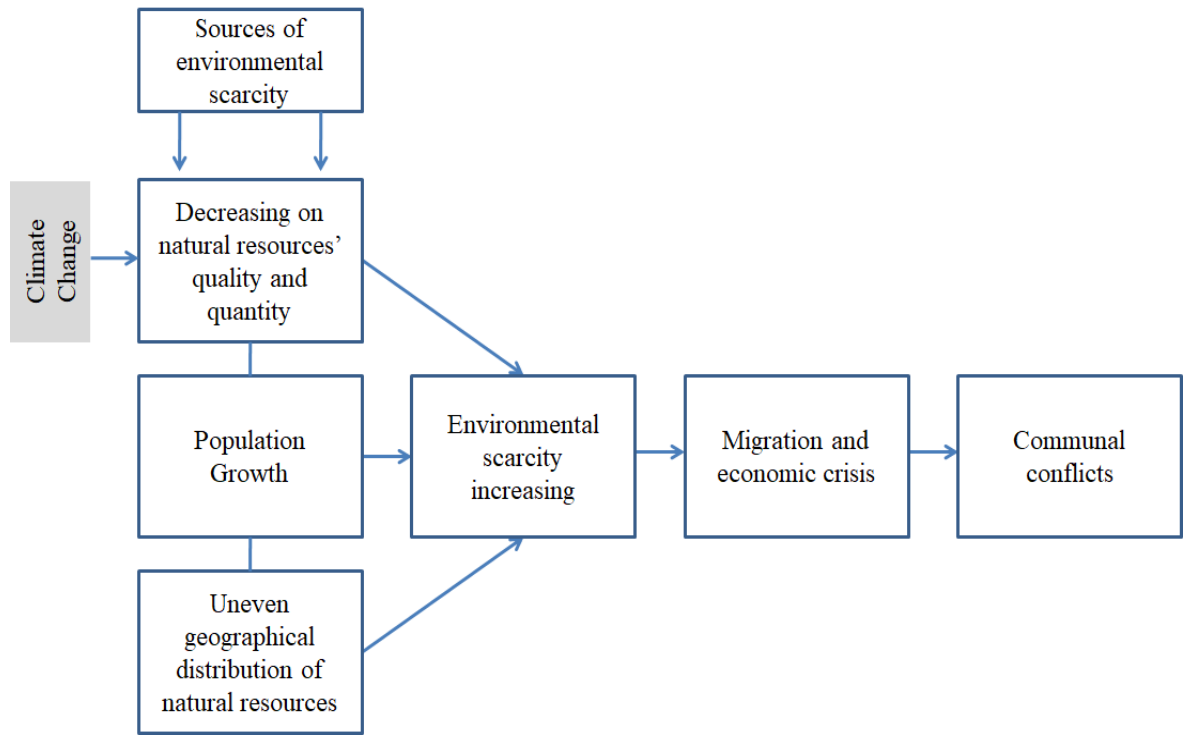

Source: Adapted from the original scheme proposed by Homer-Dixon (1994).

Africa is currently facing a series of problems arising from environmental degradation, and in the Sahel-influenced regions the greatest adversities are related to water availability, which is most visibly manifested by drought and desertification, and the negative effects are accentuated by climate change (IPCC, 2013). In addition, countries on the African continent are especially vulnerable to climate change because of their low

10 As defined by the UCDP (2016), communal conflicts are non-state and occur between groups that share lines of identity such as religion, ethnicity or belonging to the same clan or tribe. They are not permanently structured groups for combat, but sometimes they organize themselves to engage in violent conflict, and their scope tends to be intrastate. However, asserting that communal identity refers only to ethnic or religious identity may give the term a less flexible character, so ACCORD (2012) stresses that the main identification may be based on livelihood disputes, hence, communal conflicts also involve those that occur between herdsmen and farmers. 
adaptive capacity and projected negative impacts (ibid). The scarcity of natural resources has caused, for example, a series of disputes between farmers and herdsmen, as the maintenance of rural communities' livelihoods depends directly on access to such resources (Ahmadu, 2018). Central to these communal conflicts is the search for the defence of material resources, a struggle that is most evident from the scarcity of water, which is reflected, among other forms, through desertification (ibid.).

The insecurity of the natural resources necessary for the livelihoods of rural populations is pressing in Nigeria (CCASTR, 2011). It has been proved that the average temperature in Nigeria has increased $1.1^{\circ} \mathrm{C}$ since 1900 to today, and the world average temperature has risen $0.74{ }^{\circ} \mathrm{C}$ from 1860 to the present day (Akpodiogaga-a \& Odjugo, 2010). In addition, studies in the mid-1980s already pointed to a drought trend in Nigeria as a result of decreasing rainfall in the central-eastern and northern part of the country (Adefolalu, 1986). Currently, areas located in northern Nigeria have undergone a profound desertification process (Ahmadu, 2018; Nwokeoma \& Chinedu, 2017; Assibong et al., 2017), and livestock-dependent populations are directly affected, so there is an increase in population flows, especially livestock farmers, towards the centre of the country (Freeman, 2017).

West Africa, in particular Nigeria, has experienced a considerable increase in intrastate conflicts since the early 1990s, and they have been particularly worrying since the $2000 \mathrm{~s}$ with the intensification of clashes between farmers and herdsmen over natural resources, whose scarcity tends to increase, aggravated by climate change (Okoli \& Atelhe, 2014). Conflicts between farmers and herdsmen are common in almost all parts of Nigeria, and overcoming them is a major challenge for economic development, food security and the sustainability of agrarian communities (Ukamana et al., 2017). As stated earlier, the likelihood that climate effects will lead to violent conflict depends on the context, as well as on the likelihood that communal conflicts will occur in areas of natural resource scarcity (Vestby, 2018). This situation is particularly worrisome in regions where the government is not present, such as in areas where conflicts between farmers and herdsmen are triggered in the lands of central and northern Nigeria (ibid.). Tracing causality lines between climate change and conflict requires caution, as it cannot be gauged indistinctly that citizens begin to fight automatically over simple temperature increases (Buhaug, 2016; Odoh \& Chigozie, 2012).

The literature shows that the conflict between farmers and herdsmen is recurrent in Nigeria and the interaction between both dates back to ancient times, especially the Fulani group of herdsmen, whose entry into the areas that currently form the Nigerian territory dates back to the fourteenth century (Ahmadu \& Ayuba, 2018). Both the religious and ethnic biases of tensions between mostly Muslim Fulani herdsmen and predominantly Christian farmers are important in determining this communal conflict, exacerbated by scarcity of natural resources and desertification (IEP, 2017). Nigeria is can be considered a divided country and intra-state violent conflicts can quickly lead to communal conflict of an ethnic-religious dimension, as ethnic groups usually support their "lineage" in violent struggle, on the premise that group rights to which they belong should prevail (Akov, 2017).

The Fulani are a livestock raising nomadic ethnic group of about 20 million people scattered throughout West and Central Africa (Bamidele, 2018), but only a small part is involved in violent attacks in Nigeria (IEP, 2017). The Fulani ethnic group owns $90 \%$ of the country's herd, with livestock accounting for a third of the primary sector's GDP 
(Bamidele, 2018; Abbass, 2012). Problems related to water scarcity and desertification in the Sahel caused a change in the behaviour of Nigerian herdsmen, who began to look for alternatives to maintain their lifestyle in more central areas of the country (Abugu \& Onuba, 2015). The alarming desertification situation across the Sahel region has forced Fulani herders to drive their cattle to pastures located in the central and central-eastern parts of the country, also known as the Middle Belt (ibid). Fulani herdsmen have transformed the central regions of the country into permanent residence and no longer temporary residence, as was common during travels between the northern and southern extremes of Nigeria, which contributes to exacerbating the conflicts with the farmers (Akov, 2017; Abugu \& Onuba, 2015; Okoli \& Atelhe, 2014).

Conflicts between these two groups stem from competition and a desperate struggle for survival and livelihood in an environment marked by insecurity and scarcity of natural resources, a situation exacerbated by climate change (Okoli \& Atelhe, 2014; Odoh \& Chigozie, 2012; Abbass, 2012). The study by Okoli \& Atelhe (2014) identified that climate change aggravates the scenarios of water availability (desertification and drought), and, as a result, increases the migratory flow of herdsmen across Nigerian territory. The high levels of violence that has involved the Fulani ethnic group since the end of the last decade must be highlighted, and UCDP data show that this ethnic group was involved in hundreds of conflicts in Nigeria from January 2010 to December 2017, with 3,334 casualties. Most of the attacks took place in inland villages, particularly in four centrally located states (Benue, Plateau, Taraba and Nasarawa), where there were 3,085 deaths. Specifically in these four states, the Fulani came into violent conflict with groups of different ethnicities, namely: Birom, Tiv, Agatu, Eggon, Tarok, Jukun, Irigwe, Mambila, Atakar, and Bwatiye.

However, it is important to point out that in relation to the significant number of cases of fatal victims by violent attacks perpetrated by the Fulani, these acts may have a very different origin and nature, so although the dispute over natural resources is of great importance today, it should not be taken as a single factor (Chinwokwu, 2017). Criminal activities are diverse and may involve armed robbery, murder, looting, kidnapping, and destruction of communities and churches (ibid.). Most episodes involving criminal acts perpetrated by the Fulani, especially the heinous ones, are not even investigated by the government security agencies of Nigeria (ibid.). Moreover, herdsmen hardly ask permission to move or stay in any community, which in local culture is seen as sufficient affront to generate serious conflict (Bamidele, 2018). Sectors of Nigerian society criticize the actions of President Muhammadu Buhari, who, because of his belonging to the Fulani ethnic group, seems to act in a conniving manner regarding the criminal acts performed by the ethnic group to which he belongs (ibid.).

\section{Influence of the rain regime on the dynamics of the communal conflict involving the Fulani ethnicity}

In this section is presented, from a case study, how water availability, strongly marked by seasons, can be related to death events in the communal conflict between herdsmen and farmers in four Nigerian states (Benue, Plateau, Taraba and Nasarawa) in the period from January 2010 to December 2017. In these states, located in the central-eastern part of the country, the rainfall regime is marked by the presence of two distinct and well-defined seasons, rainy (May to October) and drought (November to March). 


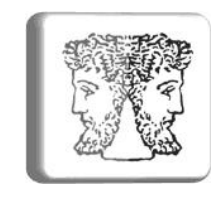

\subsection{Methodology used}

As a way of approaching the problem, the hypothetical-deductive method was adopted from a case study, which took as premise temporal and spatial criteria for the collection, processing and analysis of information. The database on violent attacks on the African continent provided by the Uppsala Conflict Data Program (UCDP), specifically Georeferenced Event Dataset (GED) Global Version 19.1 ${ }^{11}$ was used. For the purpose of meeting the proposed objectives, only information on violent conflicts with deaths in Nigeria involving the Fulani ethnicity was selected.

Regarding the time frame, the period from January 2010 to December 2017 was determined according to the escalation of events with deaths from 2010. However, it is important to highlight that the UCDP database shows sparse violent events involving the Fulani ethnicity in Nigeria since the 1990s, with a progressive increase in their frequency from the early years of this century. Thus, the data indicate that the conflict has not only been consolidated, but that they have also spread geographically from 2010 onwards. As for the number of deaths, these were based on the best estimate ${ }^{12}$ according to the UCDP categorization.

Regarding the spatial area, were analysed the events that occurred in four states in the central-eastern region of Nigeria (Plateau, Benue, Taraba and Nasarawa), the "study area" of this paper, a choice that is justified given that $92.5 \%$ of fatalities were concentrated in the period (Jan-2010 to Dec-2017), or 3,085 deaths out of a total of 3,334 fatalities (Figure 3). Moreover, the concentration of violent attacks in this part of the country corroborates the information collected in the literature, thus identifying a trend of migration from the north towards the central-eastern region of the country in search of places with greater availability of water and grassland. Events with fatalities were located on the map from the latitude and longitude information provided by the UCDP database. It should be noted that there were cases where different events involving deaths occurred in the same locality at different dates over the analysed period, in which cases the locations of the events overlapped on the map, which in these cases were identified by a single point.

In order to verify the existence of a relationship between fatalities and the occurrence of rainfall, since the variation in precipitation levels has the ability to contribute to greater or lesser water scarcity, monthly data of accumulated rainfall in millimetres were used in 15 locations ${ }^{13}$, as shown in Figure 4. With the accumulated rainfall data per location, monthly rainfall was averaged for each of the four Nigerian states from January 2010 to December 2017, for a total of 96 months. Finally, a graph was generated combining the information of the monthly rainfall index with the month of the occurrence of fatalities, according to Figures 6 to 9 .

${ }^{11}$ Available for downloading at https://ucdp.uu.se/downloads/. Accessed on 20/05/2019.

12 According to the UCDP Georeferenced Event Dataset Codebook Version 19.1, available for downloading at https://ucdp.uu.se/downloads/ged/ged191.pdf. Accessed on 20/05/2019.

13 Rainfall data used available for downloading at https://www.worldweatheronline.com. Accessed on $15 / 05 / 2019$. 
Figure 3. Area of study and location of conflict with fatalities

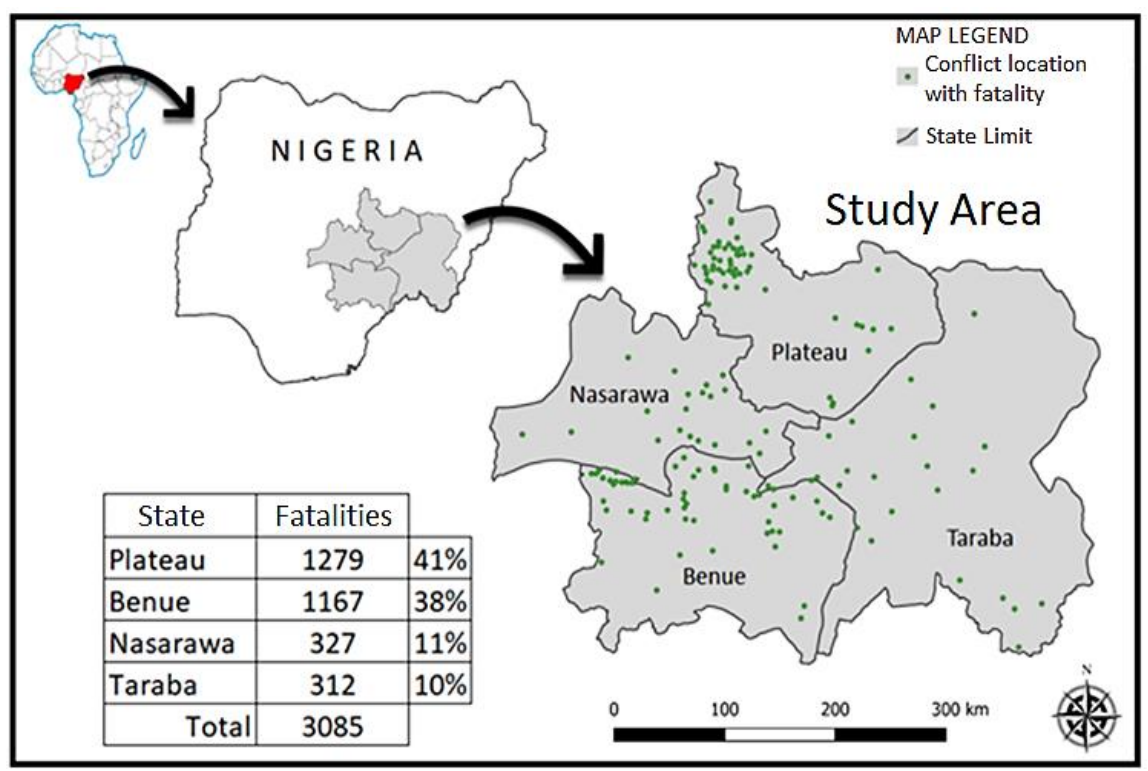

Source: Author

Regarding the tools used to verify data and generate products, spreadsheet analysis and editing software were used, also to make graphs and tables. Software was also used in GIS platform (Geographic Information System) for spatial data analysis and map production.

Figure 4. Location of rainfall data collection points in the Study Area

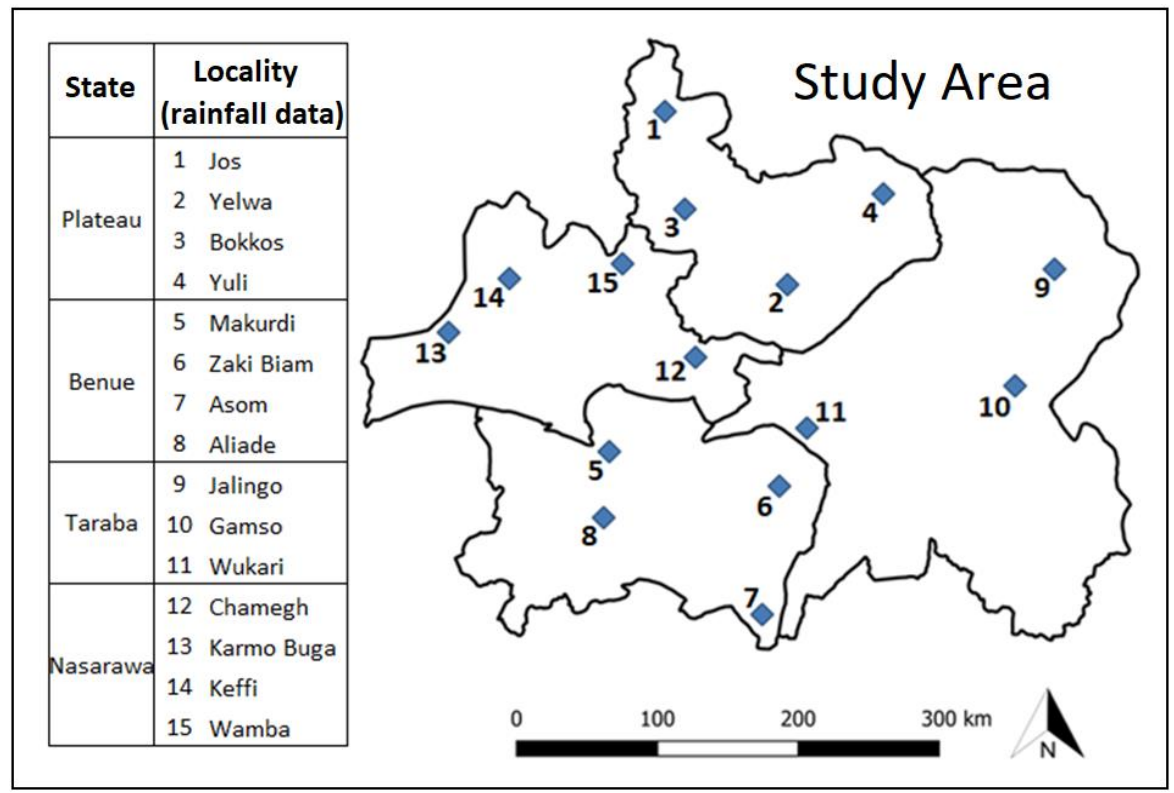

Source: Author 


\subsection{Results}

The analysis of the data shows, in the study area, that $46.4 \%$ more deaths in communal conflicts involving the Fulani ethnicity occurred in the dry season (November to April) than in the rainy season (May to October), as shown in Figure 5.

Figure 5. Distribution of deaths by time of year in the study area

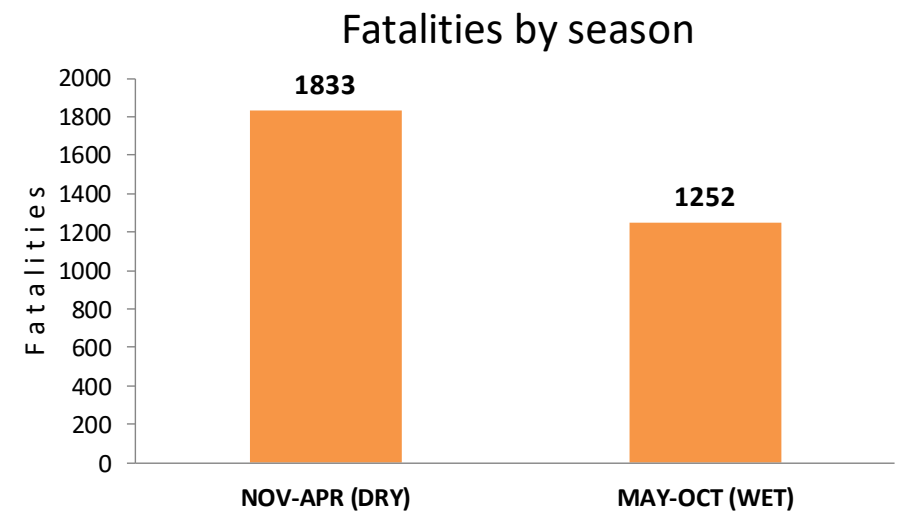

Source: Author

Regarding the distribution of deaths over the months from January 2010 to December 2017, we sought to verify the existence of a relationship between higher or lower precipitation rate with higher or lower number of fatalities. Figures 6 to 9 graphically represent the monthly average rainfall distribution with the number of deaths over the entire period analysed in each state of the study area.

Figure 6. Relationship between fatalities and rainfall (Plateau)

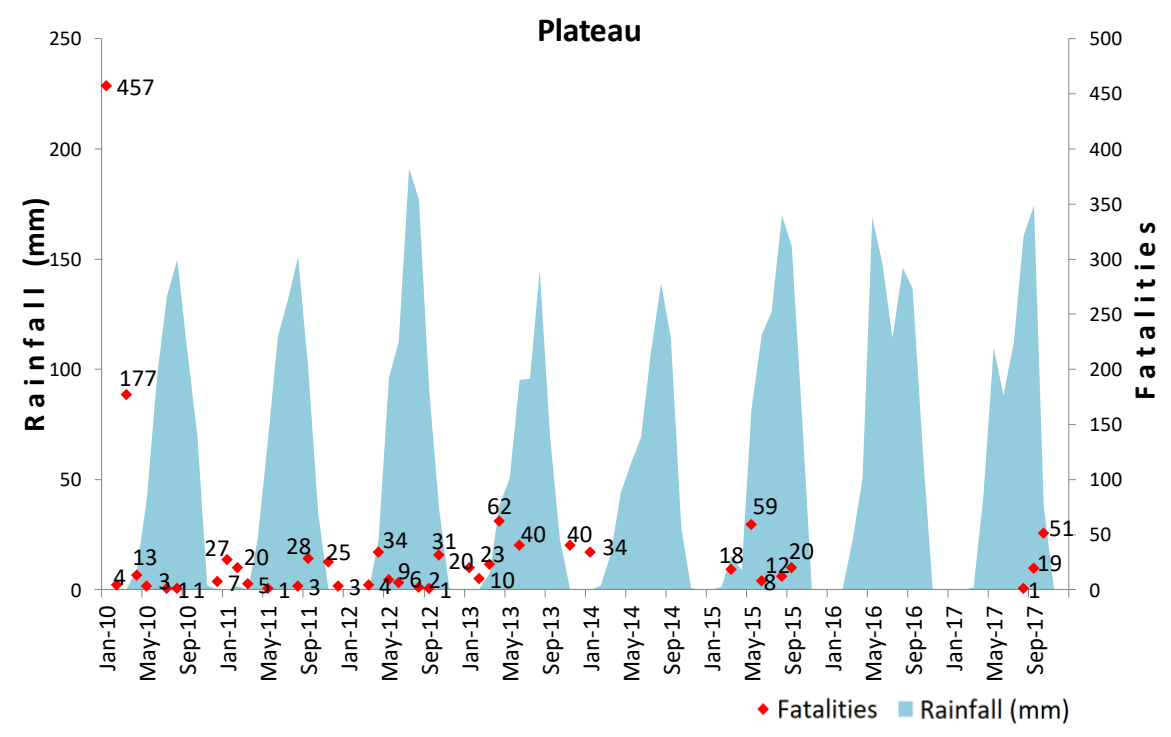

Source: Author 
Figure 7. Relationship between fatalities and rainfall (Benue)

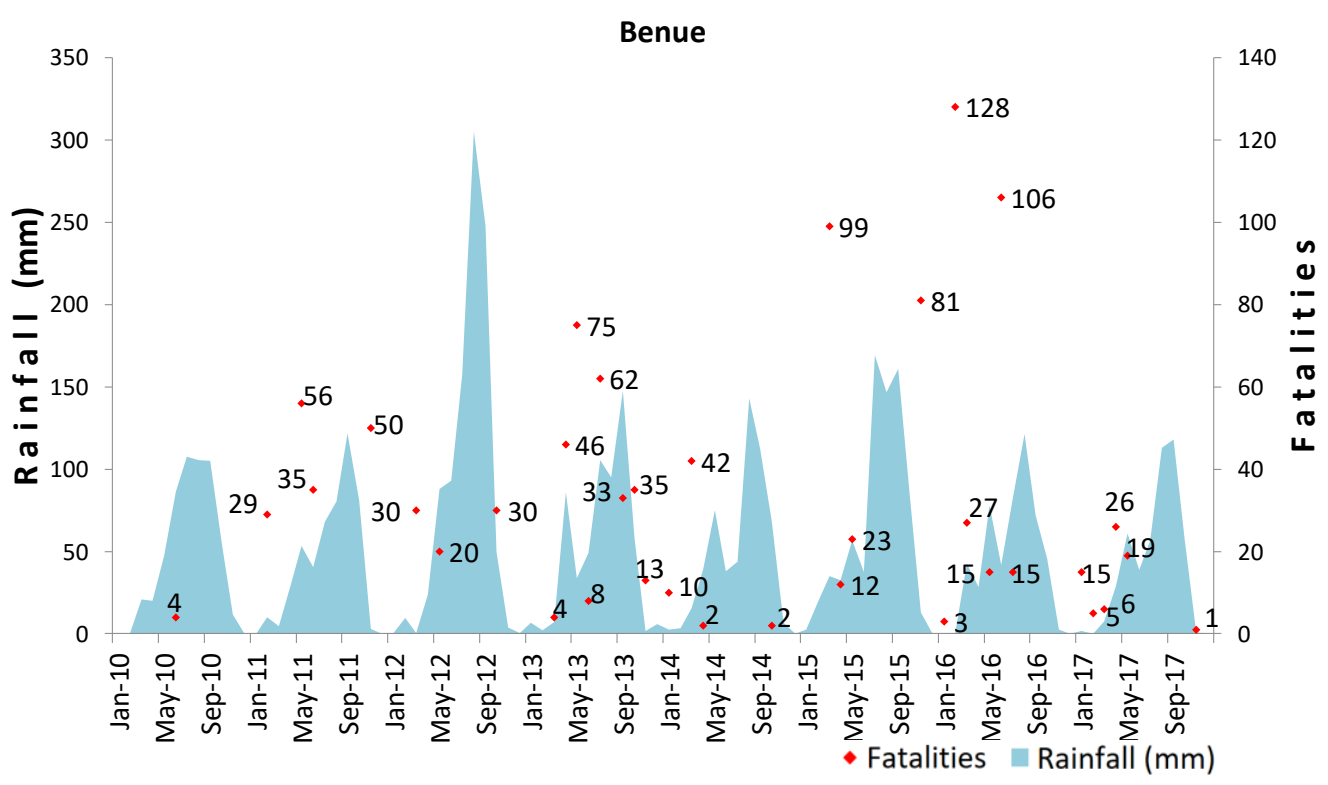

Source: Author

Figure 8. Relationship between fatalities and rainfall (Nasarawa)

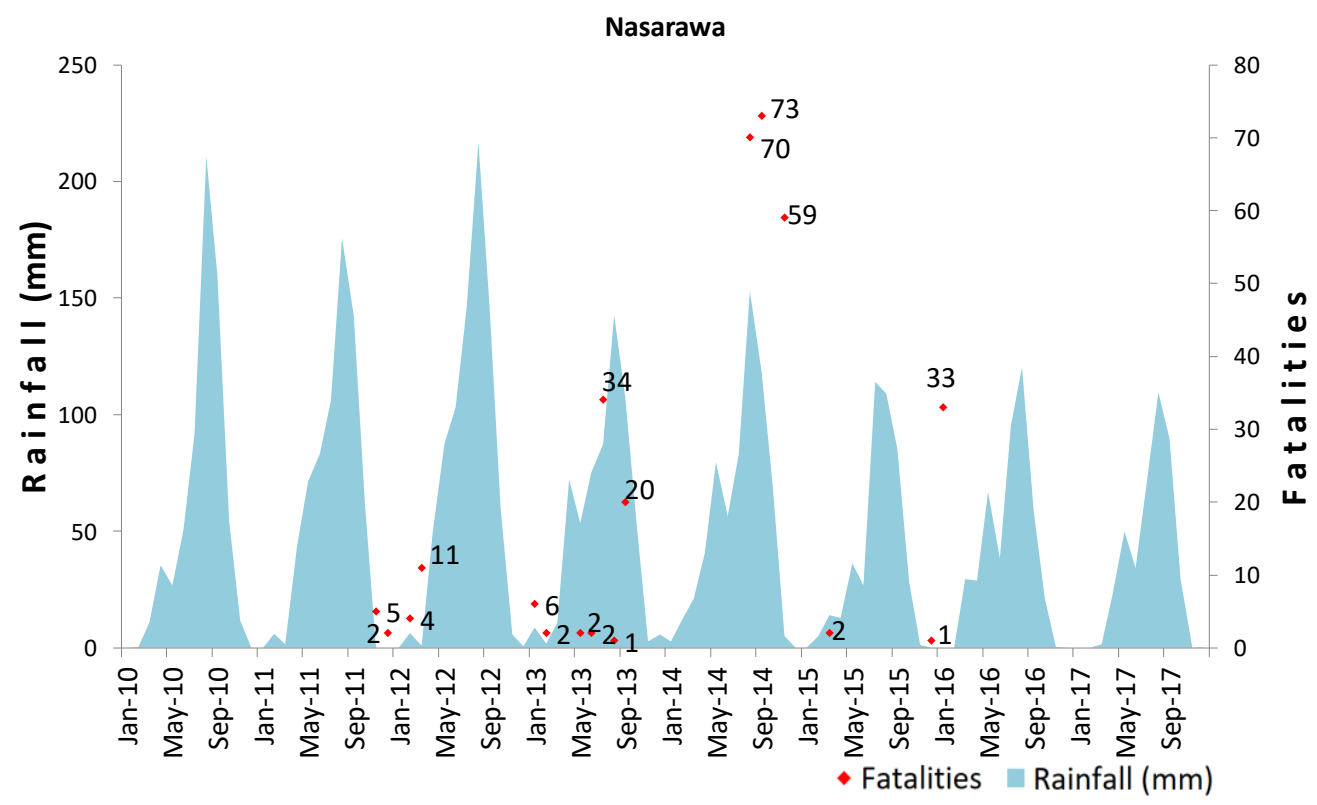

Source: Author 
Figure 9. Relationship between fatalities and rainfall (Taraba)

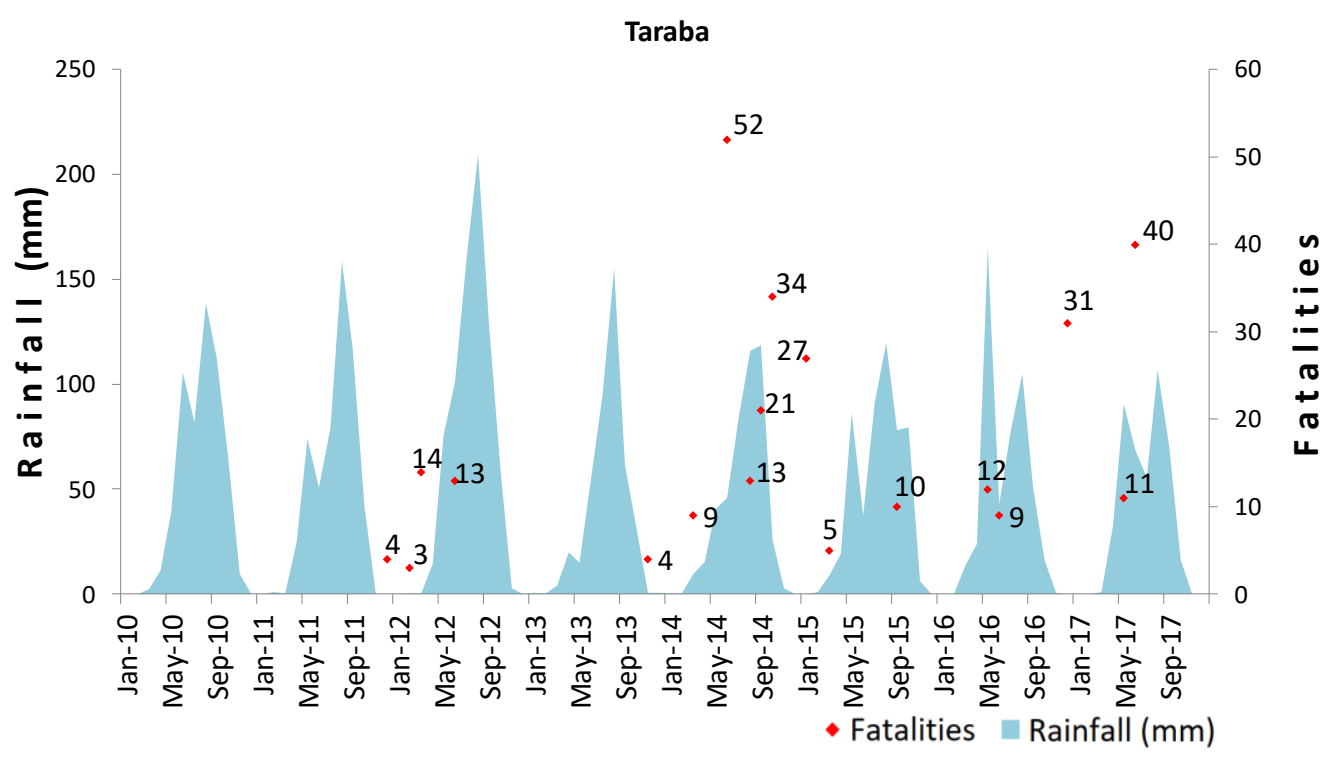

Source: Author

Although there is a higher propensity (46.4\%) of conflict with deaths occurring during the dry season (November to April), it is not possible to establish a cause-effect relationship between less rainfall and fatalities, nor to state that these attacks occurred exclusively due to the dispute over natural resources. However, it is important to highlight that the study area is comprised in the region of Nigeria where Adefolalu (1986) had already identified a lower tendency for precipitation in the dry months, especially in the central regions of the country, comprised by the parallels $7 \mathrm{~N}$ to $9 \mathrm{~N}$. Analysis of the rainfall data over the 8 years of the series (Jan 2010/Dec 2017) shows that from December to February there is virtually no rainfall, and the average annual rainfall was always below 1,000 mm, which was expected in this part of Nigeria.

\section{Conclusions}

To explain the reason behind communal conflicts, it is necessary to know the context of the object of study as broadly as possible, and then to draw conclusions, even if succinct at first, since conflicts are usually surrounded by a complex network of events. In the present case, the literature review allowed us to identify, from several studies in different sources, that the availability of natural resources, especially water and farmland, is worsening in regions of Nigeria. Scientific studies have shown that climate change plays an important role in worsening drought and desertification, which contributes to the forced displacement of rural populations from the north to the central-eastern region expecting to find natural resources to maintain their lifestyles. Therefore, although climate change cannot be considered, so far, as an element that acts directly and linearly in the origin of conflicts, its impact is relevant and its interference should be considered in communal conflicts, such as between the Fulani herders and the farmers in Nigeria. 
Therefore, it is possible to conclude that Homer-Dixon's (1994) chosen theoretical approach adequately and satisfactorily applies to the reality of the researched context.

Based on the analysis carried out in the study area during the last section of this paper, even though it was not possible to draw a dependence relationship between the higher occurrence or absence of rain with deaths caused by violent conflicts, it is possible to infer that there is a $46.4 \%$ higher probability of fatalities occurring in the drought-marked period of the year (November to May). Therefore, the causes of this greater propensity for fatal victims to occur in violent conflicts involving the Fulani in the months with or without rainfall can be worsened by the decrease in water availability due to global climate change, which is a topic for further research.

Finally, in an attempt to contribute to the resolution of the communal conflict discussed here, it is proposed that once it is understood and internalized that the impacts of climate change are a risk to human security in the country, Nigerian policy makers should strongly consider all climate change adaptation alternatives available beyond what is already underway. This is true not only for locally funded initiatives, but above all, more support and resources should be sought from more developed countries to expand investment in adaptation projects.

Not only Nigeria, but other countries located in sub-Saharan Africa should raise their demands during multilateral climate rounds, in particular under the United Nations Framework Convention on Climate Change (UNFCCC). This is because the Green Climate Fund, approved by all Parties to the Convention, should receive from developed countries $\$ 100$ billion in annual funding to finance adaptation and mitigation projects in poor countries. However, so far less than $2 \%$ of the total that should have been deposited over this decade has reached the Fund's coffers.

\section{References}

Abbass, I. M. (2012). No retreat no surrender conflict for survival between Fulani pastoralists and farmers in northern Nigeria. In European Scientific Journal. Vol. 8, no. 1.

Abugu, S. O.; Onuba, C. O. (2015). Climate change and pastoral conflicts in the middle belt and south-east Nigeria: implication on human resource of the regions. In Global Journal of Human Resource Management. Vol. 3, no. 5.

ACCORD, The African Centre for the Constructive Resolution of Disputes (2012). Climate change and conflict: Conflict-sensitive climate change adaptation in Africa.

Adefolalu, D. O. (1986). Rainfall Trends in Nigeria. In Theoretical and Applied Climatology. Vol. 37.

Ahmadu, H. J. (2018). Analysis on Some Causes and Consequences of North-South Migration of Fulani Pastoralists in Nigeria. In International Journal of Innovative Research \& Development. Vol. 7, no. 3.

Ahmadu, H. J. \& Ayuba, H. (2018). The role of group solidarity in conflict between farmers and Fulani pastoralists: A case study of Northern Nigeria. In African Journal of Political Science and International Relations. Vol. 12, no. 3. 
Akov, E. T. (2017). The resource-conflict debate revisited: Untangling the case of farmerherdsman clashes in the North Central region of Nigeria. In African Security Review. Vol. 26, no. 3 .

Akpodiogaga-a, P.; Odjugo, O. (2010). General Overview of Climate Change Impacts in Nigeria. In Journal of Human Ecology. Vol. 29, no. 1.

Assibong, P. A.; Chidozie, F.; Bakare, J. (2017). The politico-socio-economic consequences of climate change in Nigeria. In Covenant University Conference on eGovernance in Nigeria (CUCEN2017).

Bamidele, S. (2018). 'Bandidos de Terras' ou 'Grileiros': conflitos sangrentos e incessantes entre pastores Fulani e fazendeiros locais na Nigéria. In Revista Brasileira de Estudos Africanos. Vol. 3, no. 6.

Beck, U. (2016). A sociedade de risco mundial: em busca da segurança perdida. Edições 70: Lisbon.

Beck, U. (2017). A metamorfose do mundo. Edições 70: Lisbon.

Buhaug, H. (2016). Climate Change and Conflict: Taking Stock. Peace Economics. In Peace Science and Public Policy. no. 22 (4).

Burke, M.; Hsiang, S. M.; Miguel, E. (2015). Climate and Conflict. In Annual Review of Economics. no.7.

CCASTR, Climate Change Adaptation Strategy Technical Reports (2011). Building Nigeria's Response to Climate Change (BNRCC) Project.

Chinwokwu, E. C. (2017). Glamorization of Fulani herdsmen's criminality and its implications on national security in Nigeria. In Online Journal of Arts, Management and Social Sciences (OJAMSS). Vol.2, no. 2.

Conca, K. \& Wallace, J. (2012). Environment and peacebuilding in war-torn societies: Lessons from the UN Environment Programme's experience with post-conflict assessment. In Assessing and Restoring Natural Resources in Post-Conflict Peacebuilding. Jensen, D. \& Lonergan, S. (Ed.). London: Earthscan.

Dalby, S. (2017). Anthropocene Formations: Environmental Security, Geopolitics and Disaster. In Theory, Culture \& Society. Vol. 34 (2-3).

Dannreuther, R. (2013). International Security: the contemporary agenda. $2^{\text {nd }}$ Ed. Cambridge: Polity Press.

FOI, Swedish Defence Research Agency (2010). On Connecting Climate Change with Security and Armed Conflict. Department of Defence Analysis. Stockholm.

Freeman, L. (2017). Environmental change, migration, and conflict in Africa: A critical examination of the interconnection. In Journal of Environment and Development. Sage Publications.

Gbaka, E. (2014). Managing Conflict Between Farmers and Pastoralists in Benue State, Nigeria. In Peace Trends. Vol. 2, no.3.

Homer-Dixon, T. F. (1994). Environmental Scarcities and Violent Conflict: Evidence from cases. In International Security, Vol. 19, no. 1. 
Idowu, D. L. (2017). Causes, consequences and resolution of environmental conflict in Nigeria. In International Journal of Social Science and Economic Research. Vol. 02, no. 01.

IEP, Institute for Economics \& Peace (2017). Global Terrorism Index.

IPCC, Intergovernmental Panel on Climate Change (2013). The Physical Science Basis. Fifth Assessment Report.

IPCC, Intergovernmental Panel on Climate Change (2014). Climate Change 2014: Impacts, Adaptation, and Vulnerability. IPPC Working Group II.

Koubi, V. (2019). Climate Change and Conflict. In Annual Review of Political Science. Vol. 22.

Mathews, J. T. (1989). Redefining Security. In Foreign Affairs. Spring 1989.

Nwokeoma, B. N. \& Chinedu, A. K. (2017). Climate Variability and Consequences for Crime, Insurgency in North East Nigeria. In Mediterranean Journal of Social Sciences. Vol. 8, no.3.

Odoh, S.I. \& Chigozie, C. F. (2012). Climate change and conflict in Nigeria: a theoretical and empirical examination of the worsening incidence of conflict between Fulani herdsmen and farmers in northern Nigeria. Arabian Journal of Business and Management Review (OMAN Chapter). Vol. 2, no.1.

Okoli, A. C. \& Atelhe, G. A. (2014). Nomads against Natives: A Political Ecology of Herder/Farmer Conflicts in the Nasarawa State, Nigeria. In American International Journal of Contemporary Research. Vol. 4, no. 2.

Penny, C. K. (2018). Climate change as a 'threat to international peace and security'. In Climate Change and the UN Security Council. Scott, S. V. \& Ku, C. (Ed.). Cheltenham: Edward Elgar Publishing.

Raimi, L. \& Jack, J. T. C. B. (2017). How does climate change pose human security risks in the Niger delta? Implication for policy makers. In Maiduguri Journal of Arts \& Social Sciences. Vol. 14.

Salehyan, I. (2014). Climate change and conflict: Making sense of disparate findings. In Political Geography.

Scheffran, J.; Brzoska, M.; Kominek, J.; P. Link, M.; Schilling, J. (2012). Climate change and violent conflict. In Science. Vol. 336.

Scott, S. V. \& Ku, C. (2018). The UN Security Council and global action on climate change. In Climate Change and the UN Security Council. Scott, S. V. \& Ku, C. (Ed.). Cheltenham: Edward Elgar Publishing.

Sheehan, M. (2005). International Security: An analytical survey. Boulder: Lynne Rienner Publishers.

SIPRI, Stockholm International Peace Research Institute (2016). Climate-related security risks: towards an integrated approach. Stockholm.

Soromenho-Marques, V. (2015). Segurança Ambiental. In Enciclopédia de Direito e Segurança. Bacelar Gouveia, J. \& Santos, S. Coimbra: Almedina. 
Theisen, O. M.; Holtermann, H.; Buhaug, H. (2011). Climate Wars? In International Security. Vol. 36, no. 3.

Tomé, L. (2010). Security and security complex: operational concepts. In JANUS.NET ejournal of International Relations, No. 1, Autumn.

UCDP, The Uppsala Conflict Data Program (2016). Non-State Conflict Codebook. Version 2.5 .

Uexkull, N. V.; Croicu, M., Fjelde, H.; Buhaug, H. (2016). Civil conflict sensitivity to growing-season drought. Proceedings of the National Academy of Sciences of the United States of America - PNAS. no. 113 (44).

Ukamana, D. M. et al. (2017). Livelihood issues in herdsmen-farmers' conflict among farming communities in Kogi State, Nigeria. In African Journal of Agricultural Research. Vol. 12, no. 24.

UNDP, United Nations Development Programme (1994). Human Development Report 1994. New York: Oxford University Press.

UNGA, United Nations General Assembly (2009). Climate change and its possible security implications, Report of the Secretary-General. Sixty-fourth session. A/64/350.

UNSC, United Nations Security Council. (1992). S/23500. Note by the President of the Security Council. New York.

UNSC, United Nations Security Council. (2017). Resolution 2349. Adopted by the Security Council at its 7911th meeting, on 31 March 2017. New York.

Vestby, J. (2018). Climate, development, and conflict: Learning from the past and mapping uncertainties of the future. Ph.D. thesis. Department of Political Sciences, Faculty of Social Sciences, University of Oslo.

WMO, World Meteorological Organization \& GWP, Global Water Partnership (2016). Handbook of Drought Indicators and Indices. Geneva.

WTO, World Trade Organization (2010). World Trade Report 2010: Trade in Natural Resources. Geneva. 